The following tests were made :

(1) Comparison of the activity of the plasma injected immediately after the ascorbic acid had been added with the same plasma not treated. It was seen that the activity was not appreciably modified.

(2) Comparison of the activity of the two fractions obtained from the plasma after treatment with ascorbic acid; kept in the ice-chest for three hours and centrifugal separation of the precipitate from the liquid above it. (The precipitate was washed on the surface with saline solution.)

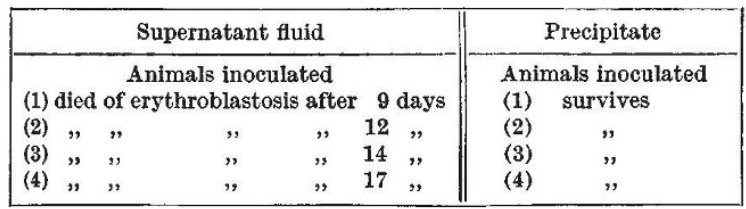

(3) Comparison of the activity of the fraction obtained after treatment of the plasma with ascorbic acid and elimination of the precipitate in the way mentioned above, with the same plasma not so treated.

\begin{tabular}{|c|c|c|c|c|c|}
\hline \multicolumn{3}{|c|}{$\begin{array}{c}\text { Plasma } \\
\text { treated }\end{array}$} & \multicolumn{3}{|c|}{$\begin{array}{l}\text { Ascorbic acid plasma } \\
\text { supernatant fluid }\end{array}$} \\
\hline $\begin{array}{l}\text { Animals } \\
\text { treated }\end{array}$ & $\begin{array}{l}\text { Posi- } \\
\text { tives }\end{array}$ & $\begin{array}{l}\text { Average } \\
\text { time of } \\
\text { survival of } \\
\text { positives }\end{array}$ & $\begin{array}{l}\text { Animals } \\
\text { treated }\end{array}$ & $\begin{array}{l}\text { Posi- } \\
\text { tives }\end{array}$ & $\begin{array}{l}\text { Average } \\
\text { time of } \\
\text { survival of } \\
\text { positives }\end{array}$ \\
\hline 21 & 15 & 19 days & 21 & 19 & 15 days \\
\hline
\end{tabular}

It seems, therefore, that the activity of the plasma treated with ascorbic acid (contrary to the results obtained by Claude ${ }^{1,2}$ by acidification with other acids of watery extracts of Rous's sarcoma) remains altogether in the supernatant fluid; and indeed, the activity seems in some degree to be increased in respect to the normal plasma.

Other researches are being carried out with plasma of fowl affected by erythro. blastosis brought, by means of lactic acid or galacturonic acid, to the same $p \mathrm{H}$, so as to ascertain whether in reality the elimination of an inactive substance from the leukæmic plasma and its successive activation is, as would seem from purely preliminary ob. servations, the consequence of an elective artion on the part of the ascorbic acid itself.

\section{E. Morelit.}

A. Vercellone.

Istituto di Perfezionamento in Chimica

\begin{tabular}{|c|c|c|c|c|c|c|}
\hline \multicolumn{3}{|c|}{ Test dose } & \multicolumn{4}{|c|}{ Excretion in fæces } \\
\hline \multirow{3}{*}{$\begin{array}{l}50 \mathrm{gm} \text { cooked spinach } \\
50 \mathrm{gm} \text {. cooked spinach } \\
+30 \mathrm{gm} \text {. lard }\end{array}$} & carotene & xanthophyl] & carotene & $\%$ & xanthophyl & $\%$ \\
\hline & $1080 \gamma$ & $3675 \gamma$ & $1017 \gamma$ & 94 & $2478 \gamma$ & 67 \\
\hline & 1660 & 4805 & 1573 & 95 & 3893 & 81 \\
\hline \multirow{2}{*}{$\begin{array}{l}100 \mathrm{gm} \text {. cooked carrots } \\
\beta \text {-carotene dissolved } \\
\text { in oil }\end{array}$} & 5700 & 370 & 5643 & 99 & 163 & 44 \\
\hline & 1056 & & 437 & 41 & & \\
\hline
\end{tabular}

Absorption of Carotinoids from the Human Intestine

IT is generally supposed that, for human beings, carotene of vegetable origin is the principal source for vitamin A. If this is true, it is important to know the absorbability of leaf carotene. We have

not detectable by ordinary analytical methods. A close study of the paper by Boyd and $D^{2}$, who have made a spectrographic analysis of a number of vegetable and animal products, revealed the fact that the manganese lines are very prominent in those vegetable products and animal tissues which are generally rich in ascorbic acid content. This led me to the investigation of the role of manganese in the

By germinating Bengal gram (Cicer arietinum) in distilled water and in dilute manganese sulphate solutions containing manganese equivalents of 1 in $10^{6}$, 1 in $10^{5}$ and 1 in $10^{4}$ for six days under identical and sterile conditions, it has been found that the ascorbic content of gram germinated in dilute manganese solutions is higher than that of gram germinated in distilled water, the respective amounts synthesized being $63 \cdot 7 \mathrm{mgm}$., $75 \cdot 5 \mathrm{mgm}$., $86 \cdot 6 \mathrm{mgm}$. and $84.7 \mathrm{mgm}$. per $100 \mathrm{gm}$. of the original dry grams. Till ascorbic acid assay was made by a modified acid in the extracts with hydrogen sulphide. The germination was better in 1 in $10^{6}$ and 1 in $10^{5}$ manganese solutions and more stunted in 1 in $10^{4}$ manganese solution than in distilled water.

Fuller details of this and experiments on animals which are in progress will be published elsewhere.

Department of Medical Chemistry,

The Prince of Wales Medical College,

\section{Patna.}

Dec. 23.

${ }^{1}$ Boyd, T. C., and De, N. K., Ind. J. Med. Res., 21, 109 (1933).

investigated this on two healthy male adults (namely, ourselves).

For one to two weeks a diet was followed which was very poor in carotinoids (bread, rice, lard, meat, Marmite and $50 \mathrm{mgm}$. ascorbic acid daily). Then the excretion of carotinoids in the fæces was determined before and after intake of a test dose of vegetables containing a known quantity of carotinoids. The fæcal carotinoids were extracted with alcoholic potash, shaken out with peroxide-free ether and after evaporation of the ether dissolved in petroleum ether. The carotinoids were estimated colorimetrically with the Zeiss stepphotometer after chromatographic analysis according to Tswett with activated aluminium oxide (Brockmann).

While on this diet, $6-10 \gamma$ carotene and $57 \gamma$ xanthophyll per $20 \mathrm{gm}$. fæees were excreted. In the accompanying table the results are summarized of the determinations of the excretion above this level after intake of different test doses. 